\title{
Determinants of Outcomes in Older Adult Patients Admitted to The Intensive Care Unit from The Emergency Department
}

\author{
Acil Servislerden Yoğun Bakım Ünitesine Kabul Edilen Yaşlı Erişkin \\ Hastaların Sonuç Belirleyicileri
}

\author{
Kamil KOKULU, Ekrem Taha SERT, Hüseyin MUTLU, Ayhan SARITAŞ
}

Acil Tıp Kliniği, Aksaray Üniversitesi Tıp Fakültesi, Aksaray

\begin{abstract}
$\ddot{\mathbf{O Z z}}$
Klinisyenler arasında yaşlı hastaların yoğun bakım ünitesine(YBÜ) kabulüne ilişkin kriterler konusunda fikir birliği bulunmamaktadır. Bu çalışmada, Acil servisten(AS) YBÜ’ye yatırılan yaşlı hastalarda AS'ye kabul sırasında değerlendirilen risk faktörlerinin mortaliteye etkisini belirlemeyi amaçladık. 1 Ocak 2019-31 Aralık 2019 tarihleri arasında YBÜ'ye kabul edilen 65 yaş ve üzeri hastalar retrospektif olarak alındı. Hastalar yaşlarına göre iki gruba ayrıldı: $65-74$ yaş, 75 yaş ve üzeri. Klinik ve demografik verileri değerlendirilmiștir; hastalar yas gruplarına göre analiz edildi. Risk faktörlerinin YBÜ'deki mortalitesine etkisi lojistik regresyon analizi kullanılarak belirlendi. Çalışmaya dahil edilen 839 hastanın \%66.3'ü 65-74 yas grubu, \%33.7'si $\geq 75$ yaş grubu idi. Hastaların \%24.7'si (n=207) öldü. Mortaliteyi etkileyen risk faktörlerinin düșük ortalama arteriyel basınç $(\mathrm{OR}=0.98$, 95\%CI:0.97-0.99), düşük Glasgow Koma Skoru $(\mathrm{OR}=0.73$, 95\% CI:0.66-0.80), entübasyon ihtiyac1 $(\mathrm{OR}=12.58$, 95\%CI:6.02-26.30), altta yatan bir kanser tanıs1 (OR $=7.23,95 \%$ CI: 2.60-20.16), ve AS'de uzun kalış süresi (OR=1.65, 95\% CI:1.46-1.87) olduğunu saptadık. Yaşın tek bașına yoğun bakımda mortalite ile ilişkili olmadığını tespit ettik $(\mathrm{p}=0.122)$. Mortaliteyi etkileyen risk faktörleri göz önünde bulundurularak AS'den YBÜ'ye kabulü düşünülmelidir.
\end{abstract}

Anahtar Kelimeler: Acil Servis, Mortalite, Yaşlı Erişkin Hastalar, Yoğun Bakım Ünitesi

\section{Introduction}

The intensive care unit (ICU) is a specialized unit for close follow-up and comprehensive treatment of critically ill patients with rapidly deteriorating clinical parameters. As the population ages, the demand for medical resources continues to increase, and the number of older adult patients presenting to the emergency department (ED) and are admitted to the ICU is increasing (1). However, there remains no consensus among clinicians on the criteria for the admission of older adult patients to the ICU. Many clinicians are reluctant to admit older adult patients to the ICU because these patients benefit less from the ICU, have increased morbidity and mortality

\begin{tabular}{|c|c|}
\hline & ORCID No \\
\hline Kamil KOKULU & 0000-0002-6123-0898 \\
\hline Ekrem Taha SERT & $0000-0002-7208-2186$ \\
\hline Hüseyin MUTLU & 0000-0002-1930-3293 \\
\hline Ayhan SARITAŞ & $0000-0002-4302-1093$ \\
\hline Başvuru Tarihi / Received: & 22.11 .2020 \\
\hline Kabul Tarihi / Accepted : & 14.09 .2021 \\
\hline Adres / Correspondence : & Hüseyin MUTLU \\
\hline \multicolumn{2}{|c|}{ Acil Tıp Kliniği, Aksaray Üniversitesi Tıp Fakültesi, Aksaray } \\
\hline e-posta / e-mail & hmutlu70@hotmail.com \\
\hline
\end{tabular}

\begin{abstract}
There is no consensus among clinicians on the criteria for admission of older adult patients to the intensive care unit (ICU). In this study, we aimed to determine the impact of risk factors assessed during admission to the emergency department (ED) in older adult patients admitted to the ICU from the ED on ICU mortality. Patients aged 65 years or older, who were admitted to the ICU between January 1, 2019, and December 31, 2019, were retrospectively evaluated. Patients were divided into two groups according to their age: 65-74 years old and 75 years and older. Clinical and demographic data were evaluated and patients were analyzed according to the age groups. The association of risk factors on ICU mortality was determined using logistic regression analysis. Of the 839 patients included in the study, $66.3 \%$ were in the $65-74$ age group and $33.7 \%$ were in the $\geq 75$ age group. A proportion of $24.7 \%$ of the patients $(n=207)$ died. The risk factors associated with ICU mortality were low mean arterial pressure ( $\mathrm{OR}=0.98,95 \% \mathrm{CI}: 0.97-0.99)$, low Glasgow Coma Scale score (OR=0.73, 95\% CI:0.66-0.80), intubation requirement $(\mathrm{OR}=12.58,95 \% \quad \mathrm{CI}: 6.02-26.30)$, underlying cancer diagnosis $(\mathrm{OR}=7.23,95 \% \mathrm{CI}: 2.60-20.16)$, and long stay in the $\mathrm{ED}(\mathrm{OR}=1.65,95 \% \mathrm{CI}: 1.46-1.87)$. Age alone was not associated with ICU mortality $(\mathrm{p}=0.122)$. Admission to the ICU from the ED should consider the risk factors associated with ICU mortality.

Keywords: Emergency Department, Intensive Care Unit, Older Adult Patients, Mortality
\end{abstract}

with intensive treatment, are more exposed to iatrogenic complications, and have lower quality of life, and the efficiency of medical resources is reduced (2,3). Another view is that the abovementioned problems are not associated with age but with the severity of the underlying disease $(4,5)$. This discrepancy is due to the lack of proven criteria that accurately identify older adult patients who can benefit most from admission to the ICU (6). Despite the fact that the need for intensive care is higher in older adult patients, a study investigating ICU admissions of older adult patients, revealed that $27.9 \%$ of patients in the 75-84-year age group were admitted to the ICU, and this ratio decreased to $21.1 \%$ in patients over 85 years of age (7). A study conducted in 15 emergency units, demonstrated that intensive care physicians were extremely reluctant to admit patients to the ICU who were aged above 80 years and met the criteria for admission to the ICU (8).

Although guidelines on the admission of critically ill patients to the ICU have been developed, these guidelines do not contain sufficient information on which patients should be admitted to the ICU, which patients should be admitted to an acute care ward, and which patients should be 
admitted to a palliative care ward (9). In the present study, we evaluated the clinical characteristics of patients aged 65 years and older who presented to the ED and were admitted to the ICU. We aimed to determine the ICU mortality rate in these patients and the association of risk factors assessed during admission to the ED on ICU mortality.

\section{Material and Method}

This retrospective study was conducted between January 1, 2019, and December 31, 2019 in the tertiary ED of our hospital, and local ethics committee approval was obtained for the study (Ethical Committee of Aksaray University Faculty of Medicine with a protocol number of 2020/03-56 and conducted in accordance with the Declaration of Helsinki and Good Clinical Practices). A total of 839 patients aged 65 years and older who presented to the ED and were admitted to the ICU were included in the study.

Patients aged less than 65 years, with a history of trauma, whose records were not accessible, who were transferred to another hospital without conclusion of treatment for any reason, or who were admitted to the ICU after cardiac arrest and underwent cardiopulmonary resuscitation were excluded from the study. In addition, read mission to the ICU is associated with unfavorable results, such as longer hospital stays, higher in-hospital mortality and increased adverse events (10). Therefore, for patients with multiple ICU stays during the study period, only the data from the first ICU stay were used in the study. The flow diagram of patient selection is shown in Figure 1.

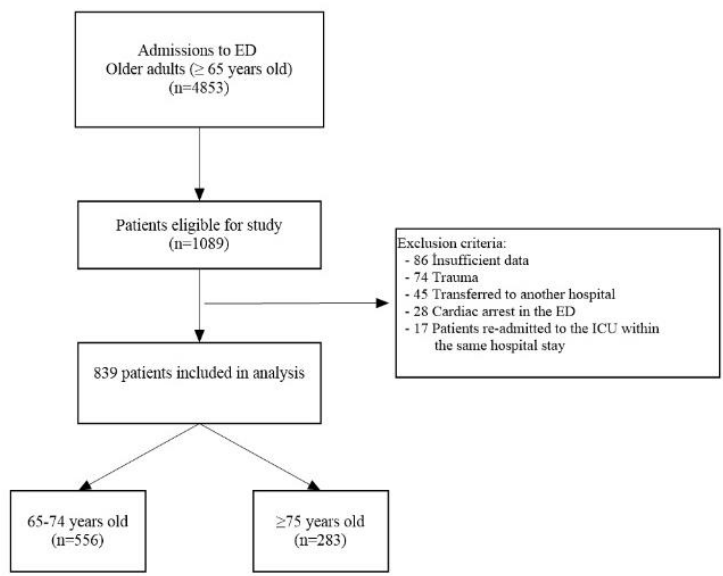

Figure 1. Flow chart of the study selection process.

Patients were divided into two groups according to their age: $65-74$ years and 75 years and older. The clinical and demographic characteristics of the patients in each age group and ICU mortality rates were compared. In addition, the association of patients' clinical characteristics at admission to the ED on ICU mortality were assessed.

Comorbidities were evaluated using the Charlson Comorbidity Index (CCI) (11). The length of ED stay was defined as the period from patient triage and admission to the ED until admission to the ICU.

The primary outcome measure was mortality of patients who were admitted from the ED to the ICU. This measure was used to determine ICU mortality rates of patients aged 65 years and older who were admitted to the ICU. The secondary outcome was measuring the association that the clinical features present at the time of admission to the ED had on ICU mortality. Therefore, risk factors that associated with ICU mortality in older adult patients were identified.

Statistical analysis was performed using SPSS 17.0 program (SPSS Inc, Chicago, IL, USA). Continuous variables were presented as mean \pm standard deviation and median (25th-75th percentile), and categorical variables were expressed as frequency (percentage). Conformity to normal distribution was tested using Kolmogorov-Smirnov test. Student's t-test was used for comparing normally distributed data, Mann-Whitney U test was used for comparing non-normally distributed data and Pearson's chi-square or Fisher's test was used for comparing categorical variables. Univariate and multivariate logistic regression analyses were performed to determine the relationship between ICU mortality after admission to the ICU and possible clinical variables. Statistically significant variables $(\mathrm{p}<0.05)$ in the univariate analysis were further analyzed with multivariate logistic regression using the forward stepwise method. Odds ratios and 95\% confidence intervals were used to predict the relationship between independent determinants of ICU mortality. $\mathrm{P}<0.05$ was considered statistically significant for multivariate logistic regression analysis and other tests.

\section{Results}

Our study included 839 patients of whom, $66.3 \%$ were $65-74$ years of age and $33.7 \%$ were $\geq 75$ years of age. The mean age of the patients was $76 \pm 5$ years, with $48 \%(n=402)$ being males and $52 \%(n=437)$ females. The demographic and clinical characteristics of the patients according to the age groups are shown in Table 1. There was no statistically significant difference between the two age groups in terms of genders $(p>0.05)$. There was also a statistically significant difference between the age groups in terms of GCS, mean arterial pressures and systolic and diastolic blood pressures at the time of admission to the ED ( $p<0.05)$.

In terms of the concomitant comorbidities of the patients, there were higher rates of hypertension, diabetes mellitus, and chronic respiratory system diseases in the 65-74-year-old age group than in the age group $\geq 75$ years $(51.3 \%, 31.5 \%, 31.3 \%$, respectively) (Table 2). There was no statistically significant difference between the age groups in terms of comorbidities ( $p>0.05)$, but there was a 
significant difference between the CCI scores $(\mathrm{p}=0.020)$. The most common complaint at admission among both groups was dyspnea (65-74year-old age group: $33.3 \%$; $\geq 75$-years age group: $35.7 \%$ ). There was no significant difference between the age groups in terms of complaints at admission $(\mathrm{p}>0.05)$.

The diagnoses on admission to ICU and clinical outcomes of the patients in both age groups are shown in Table 3. Among all the patients, the most common reason for admission to the ICU was diseases of the respiratory system $(22.1 \%)$. There was no significant difference between the age groups in terms of reasons for hospitalization ( $p>0.05)$. When all patients were evaluated, it was found that $9.1 \%$ (77) needed noninvasive mechanical ventilation and $7.2 \%$ (61) needed endotracheal intubation.

The median duration of the ED stays among patients admitted to the ICU was 2.93 (2.1-3.6) hours. In terms of the age groups, the durations of the ED stays were shorter among the 65-74-year-old age group with a median time of $2.7(2-3.4)$ hours in comparison to the $\geq 75$-years age group in which there was a median time of $3.3(2.3-3.9)$ hours $(p<0.001)$. There was no significant difference between the groups in terms of the durations of the ICU stays $(p=0.143)$. In addition, $64.1 \%$ of the patients, who were followed in the ICU then went to patient wards, $11.2 \%$ were discharged, and $24.7 \%$ died.

ICU mortality rates were $23.9 \%$ in the $65-74$ year-old age group and $26.1 \%$ inthe $\geq 75$-years age $\operatorname{group}(\mathrm{p}=0.479)$. Multivariate logistic regression analyses were performed to identify the factors associated with ICU mortality and to determine the degree to which these factors increased the risk of ICU mortality (Table 4). Regression analysis revealed that low MAP sat admission to the ED $(\mathrm{OR}=0.98$, 95\% CI:0.97-0.99), low GCSs $(\mathrm{OR}=0.73$, 95\% CI:0.66-0.80), underlying cancer diagnoses $(\mathrm{OR}=7.23,95 \%$ CI: $2.60-20.16)$, intubation at the $\mathrm{ED}(\mathrm{OR}=12.58$, 95\% CI:6.02-26.30), and prolonged stays at the ED $(\mathrm{OR}=1.65,95 \%$ CI:1.46-1.87) increased ICU mortality. Age and other variables did not show significant correlations with the increased risk of ICU mortality ( $p>0.05)$.

\section{Discussion}

To the best of our knowledge, this is the first study to investigate the relationship between ICU mortality and risk factors assessed during admission to the ED in patients aged 65 years and older. We observed significant differences between many clinical characteristics and ICU mortality in patients aged 65 and older transferred from the ED to the ICU. The ICU mortality rate during intensive care stay was $24.7 \%$ overall, $23.9 \%$ in the $65-74$-year-old age group, and $26.1 \%$ in the $\geq 75$-years age group.
We found that the most important risk factors for ICU mortality were low MAP, and GCS, the need for intubation, underlying cancer diagnosis, and prolonged stay in the ED.

Studies investigating the association of age on ICU mortality rates have reported contradictory results. Vosylius et al. (12), reported higher morbidity and mortality rates in older patients compared with younger patients admitted to the ICU, with a mortality rate in patients aged over 75 years twice that of patients aged under 65 years. Furchet al. (13) found that the ICU mortality rate increased in patients over 75 years of age and that age was an independent risk factor for mortality. Conversely, Somme et al. (14) found no difference between $75-79,80-84$, and $\geq 85$ years in terms of ICU survival. Similarly, many other studies have suggested that age alone is not associated with ICU mortality $(15,16)$. In line with these studies, our study found that age is not a key risk factor and that physiological condition had a more significant effect on ICU mortality. Therefore, age alone is not a reliable indicator for the use of intensive care resources.

Studies evaluating older adult patient mortality in ICUs have shown that age, gender, mechanical ventilation, cardiogenic shock, and underlying diseases are associated with poor outcomes $(17,18)$. Hwang et al. (19) showed that risk factors associated with mortality in older adult patients admitted to the ICU included an age $>85$ years and transfer from the $\mathrm{ED}$, suggesting that more attention should be paid to patients who were referred to the ICU by the ED. Another study on ICU patients emphasized the importance of acute physiological disorders, severe cognitive impairment and activity status at admission in terms of hospital prognosis (20).

The commonly used ICU scoring systems include patient age but do not include the patient's pre-hospital functional status or functional insufficiency, comorbidities $(21,22)$. Indices such as the Acute Physiology and Chronic Health Evaluation II score and Simplified Acute Physiology Score II are frequently used to predict hospital mortality of patients in ICUs $(21,22)$. However, these indices require evaluation of laboratory data based on physiological disorders in the first 24 hours of ICU stay and therefore may not be appropriate assessment methods for patients treated in the ED. For this reason, these scoring systems were not used in this study. We used the CCI based on anamnesis information upon admission to the hospital (11). Studies comparing the prognostic value of this comorbidity index with standard indices for intensive care patients have shown that it can be used as an alternative method (23). In our study, although there was no significant difference between age groups in terms of comorbidities, there was a significant difference in CCI scores. However, multiple regression analysis revealed that the CCI 
Table 1. Baseline characteristics of patients according to age group and survival status

\begin{tabular}{|c|c|c|c|c|c|c|}
\hline \multirow[t]{2}{*}{ Variable } & \multicolumn{2}{|c|}{ Age group } & \multirow[b]{2}{*}{$\mathrm{p}$ value } & \multicolumn{2}{|c|}{ Survival status } & \multirow[b]{2}{*}{$\mathrm{p}$ value } \\
\hline & $\begin{array}{l}\text { 65-74 years } \\
(\mathrm{n}=556)\end{array}$ & $\begin{array}{l}\geq 75 \text { years } \\
(\mathrm{n}=283)\end{array}$ & & $\begin{array}{l}\text { Survivors } \\
(\mathrm{n}=632)\end{array}$ & $\begin{array}{l}\text { Non-survivors } \\
(\mathrm{n}=207)\end{array}$ & \\
\hline Age (years) ${ }^{\dagger}$ & $71(67-72)$ & $79(77-83)$ & $<0.001$ & $82(78-86)$ & $82(78-86)$ & 0.849 \\
\hline Gender, n (\%) & & & 0.070 & & & 0.406 \\
\hline Female & $302(54.3 \%)$ & $135(47.7 \%)$ & & $324(51.3)$ & $113(54.6)$ & \\
\hline Male & $254(45.7 \%)$ & $148(52.3 \%)$ & & $308(48.7)$ & $94(45.4)$ & \\
\hline \multicolumn{7}{|l|}{ Vital sign ${ }^{\dagger}$} \\
\hline Systolic BP (mmHg) & $120(100-143)$ & $110(100-130)$ & 0.008 & $120(100-143)$ & $100(94-120)$ & $<0.001$ \\
\hline Diastolic BP (mmHg) & $74(60-90)$ & $70(60-85)$ & 0.019 & $80(60-90)$ & $63(58-80)$ & $<0.001$ \\
\hline HR (beats/min) & $96(86-112)$ & $102(87-112)$ & 0.175 & $96(87-112)$ & $98(87-111)$ & 0.860 \\
\hline RR (breath/min) & $20(20-23)$ & $20(20-24)$ & 0.118 & $20(20-22)$ & $20(20-24)$ & 0.122 \\
\hline Body temperature $\left({ }^{\circ} \mathrm{C}\right)$ & $36.9(36.7-37.0)$ & $36.9(36.6-37.0)$ & 0.653 & $36.9(36.6-37.0)$ & $37.0(36.7-37.1)$ & 0.064 \\
\hline Oxygen saturation (\%) & $94(89-96)$ & $94(89-96)$ & 0.921 & $94(89-96)$ & $93(89-95)$ & 0.143 \\
\hline MAP & $90(73-106)$ & $83(73-97)$ & 0.023 & $91(76-106)$ & $76(68-93)$ & $<0.001$ \\
\hline $\mathrm{GCS}$ at admission ${ }^{\dagger}$ & $14(12-15)$ & $13(11-14)$ & 0.001 & $14(13-15)$ & $12(11-14)$ & $<0.001$ \\
\hline
\end{tabular}

$\dagger$ Median and 25-75 percentiles; BP: blood pressure; HR: heart rate; RR, respiratory rate; MAP: mean arterial pressure; GCS: Glasgow Coma Scale; ED: emergency department

Table 2. Comorbidities and chief complaints of patients according to age group and survival status

\begin{tabular}{|c|c|c|c|c|c|c|}
\hline \multirow[t]{2}{*}{ Variable } & \multicolumn{2}{|c|}{ Age group } & \multicolumn{4}{|c|}{ Survival status } \\
\hline & $\begin{array}{l}\text { 65-74 years } \\
(\mathrm{n}=556)\end{array}$ & $\begin{array}{l}\geq 75 \text { years } \\
(n=283)\end{array}$ & $\mathrm{p}$ value & $\begin{array}{l}\text { Survivors } \\
(\mathrm{n}=632)\end{array}$ & $\begin{array}{l}\text { Non-survivors } \\
(\mathrm{n}=207)\end{array}$ & $\mathrm{p}$ value \\
\hline \multicolumn{7}{|l|}{ Comorbidities } \\
\hline Hypertension & $285(51.3 \%)$ & $129(45.6 \%)$ & 0.120 & $313(49.5 \%)$ & $101(48.8 \%)$ & 0.855 \\
\hline Diabetes mellitus & $175(31.5 \%)$ & $84(29.7 \%)$ & 0.595 & $186(29.4 \%)$ & $73(35.3 \%)$ & 0.115 \\
\hline Coronary artery disease & $77(13.8 \%)$ & $31(11 \%)$ & 0.237 & $75(11.9 \%)$ & $33(15.9 \%)$ & 0.129 \\
\hline Congestive heart failure & $128(\% 23 \%)$ & $55(19.4 \%)$ & 0.234 & $137(21.7 \%)$ & $46(22.2 \%)$ & 0.869 \\
\hline Cerebrovascular disease & $49(8.8 \%)$ & $31(11 \%)$ & 0.318 & $61(9.7 \%)$ & $19(9.2 \%)$ & 0.841 \\
\hline Chronic respiratory disease & $174(31.3 \%)$ & $93(32.9 \%)$ & 0.645 & $208(32.9 \%)$ & $59(28.5 \%)$ & 0.237 \\
\hline Chronic kidney disease & $73(13.1 \%)$ & $32(11.3 \%)$ & 0.451 & $84(13.3 \%)$ & $21(10.1 \%)$ & 0.235 \\
\hline Chronic liver disease & $16(2.9 \%)$ & $9(3.2 \%)$ & 0.807 & $22(3.5 \%)$ & $3(1.4 \%)$ & 0.136 \\
\hline Alzheimer's / Dementia & $83(14.9 \%)$ & $31(11 \%)$ & 0.112 & $80(12.7 \%)$ & $34(16.4 \%)$ & 0.170 \\
\hline Cancer & $17(3.1 \%)$ & $6(2.1 \%)$ & 0.432 & $7(1.1 \%)$ & $16(7.7 \%)$ & $<0.001$ \\
\hline \multicolumn{7}{|l|}{ Admission complaints } \\
\hline Abdominal pain or discomfort & $141(25.4 \%)$ & $86(30.4 \%)$ & 0.121 & $180(28.5 \%)$ & $47(22.7 \%)$ & 0.104 \\
\hline Dyspnea of chief compliant & $185(33.3 \%)$ & $101(35.7 \%)$ & 0.485 & $231(36.6 \%)$ & $55(26.6 \%)$ & 0.009 \\
\hline Chest pain or discomfort & $139(25 \%)$ & $75(26.5 \%)$ & 0.637 & $163(25.8 \%)$ & $51(24.6 \%)$ & 0.741 \\
\hline Nausea / vomiting & $103(18.5 \%)$ & $47(16.6 \%)$ & 0.493 & $116(18.4 \%)$ & $34(16.4 \%)$ & 0.530 \\
\hline Fever & $134(24.1 \%)$ & $64(22.6 \%)$ & 0.632 & $141(22.3 \%)$ & $57(27.5 \%)$ & 0.124 \\
\hline Dizziness & $43(7.7 \%)$ & $19(6.7 \%)$ & 0.593 & $51(8.1 \%)$ & $11(5.3 \%)$ & 0.188 \\
\hline Headache & $40(7.2 \%)$ & $13(4.6 \%)$ & 0.145 & $43(6.8 \%)$ & $10(4.8 \%)$ & 0.307 \\
\hline Gastrointestinal bleeding & $22(4 \%)$ & $10(3.5 \%)$ & 0.762 & $26(4.1 \%)$ & $6(2.9 \%)$ & 0.428 \\
\hline Mental change & $70(12.6 \%)$ & $31(11 \%)$ & 0.491 & $65(10.3 \%)$ & $36(17.4 \%)$ & 0.006 \\
\hline Motor weakness & $79(14.2 \%)$ & $30(10.6 \%)$ & 0.142 & $85(13.4 \%)$ & $24(11.6 \%)$ & 0.491 \\
\hline Dysarthria & $36(6.5 \%)$ & $12(4.2 \%)$ & 0.188 & $39(6.2 \%)$ & $9(4.3 \%)$ & 0.327 \\
\hline Other & $41(7.4 \%)$ & $18(6.4 \%)$ & 0.587 & $50(7.9 \%)$ & $9(4.3 \%)$ & 0.082 \\
\hline
\end{tabular}

Table 3. Clinical outcome of patients according to age group and survival status

\begin{tabular}{|c|c|c|c|c|c|c|}
\hline \multirow[t]{2}{*}{ Variable } & \multicolumn{2}{|c|}{ Age group } & \multirow[b]{2}{*}{$\mathrm{p}$ value } & \multicolumn{2}{|c|}{ Survival status } & \multirow[b]{2}{*}{$\mathrm{p}$ value } \\
\hline & $\begin{array}{l}\text { 65-74 years } \\
(\mathrm{n}=556)\end{array}$ & $\begin{array}{l}\geq 75 \text { years } \\
(\mathrm{n}=283)\end{array}$ & & $\begin{array}{l}\text { Survivors } \\
(\mathrm{n}=632)\end{array}$ & $\begin{array}{l}\text { Non-survivors } \\
(\mathrm{n}=207)\end{array}$ & \\
\hline ICU admission diagnoses & & & 0.225 & & & 0.001 \\
\hline Respiratory disease & $149(26.8 \%)$ & $87(30.7 \%)$ & & $165(26.1 \%)$ & $71(34.3 \%)$ & \\
\hline Infectious disease & $134(24.1 \%)$ & $64(22.6 \%)$ & & $163(25.8 \%)$ & $35(16.9 \%)$ & \\
\hline Cardiovascular disease & $73(13.1 \%)$ & $27(9.5 \%)$ & & $72(11.4 \%)$ & $28(13.5 \%)$ & \\
\hline Cerebrovascular diseases & $47(8.5 \%)$ & $18(6.4 \%)$ & & $55(8.7 \%)$ & $10(4.8 \%)$ & \\
\hline Endocrine-metabolic diseases & $42(7.6 \%)$ & $17(6 \%)$ & & $51(8.1 \%)$ & $8(3.9 \%)$ & \\
\hline Renal disease & $39(7 \%)$ & $32(11.3 \%)$ & & $50(7.9 \%)$ & $21(10.1 \%)$ & \\
\hline Gastrointestinal diseases & $37(6.7 \%)$ & $17(6 \%)$ & & $31(4.9 \%)$ & $23(11.1 \%)$ & \\
\hline Hematologic disease & $7(1.3 \%)$ & $8(2.8 \%)$ & & $12(1.9 \%)$ & $3(1.4 \%)$ & \\
\hline Oncologic disease & $9(1.6 \%)$ & $4(1.4 \%)$ & & $9(1.4 \%)$ & $4(1.9 \%)$ & \\
\hline Other & $19(3.4 \%)$ & $9(3.2 \%)$ & & $24(3.8 \%)$ & $4(1.9 \%)$ & \\
\hline Charlson comorbidity index & $2(1-3)$ & $2(1-3)$ & 0.020 & $2(1-3)$ & $2(1-3)$ & 0.024 \\
\hline Non-invasive MV n (\%) & $56(10.1 \%)$ & $21(6.7 \%)$ & 0.107 & $53(8.4 \%)$ & $22(10.6 \%)$ & 0.326 \\
\hline Intubation at ED & $40(7.2 \%)$ & $21(7.4 \%)$ & 0.905 & $12(1.9 \%)$ & $49(23.7 \%)$ & $<0.001$ \\
\hline Length of stay in the ED (hour) & $2.7(2-3.4)$ & $3.3(2.3-3.9)$ & $<0.001$ & $2.7(2 .-3.4)$ & $3.4(2.4-5.2)$ & $<0.001$ \\
\hline Length of stay in the ICU, days & $2(1-5)$ & $2(1-6)$ & 0.143 & $2(1-5)$ & $3(1-11)$ & $<0.001$ \\
\hline ICU mortality, $\mathrm{n},(\%)$ & $133(23.9 \%)$ & $74(26.1 \%)$ & 0.479 & & & \\
\hline Transfer to in-patient services & $360(64.7 \%)$ & $178(62.9 \%)$ & $<0.001$ & & & \\
\hline Treated and discharged & $63(11.3 \%)$ & $31(11.0 \%)$ & 0.001 & & & \\
\hline
\end{tabular}


Table 4. Multivariate analysis of predictive factors for ICU mortality.

\begin{tabular}{lllc}
\hline Variables & \multicolumn{3}{c}{ Multivariate logistic regression } \\
\cline { 2 - 4 } & OR & $95 \%$ CI & p value \\
\hline MAP & 0.978 & $0.967-0.988$ & $<\mathbf{0 0 1}$ \\
GCS at admission & 0.727 & $0.664-0.797$ & $\mathbf{0 . 0 0 1}$ \\
Dyspnea of chief compliant & 0.648 & $0.426-1.087$ & 0.053 \\
Cancer & 7.233 & $2.595-20.160$ & $\mathbf{0 . 0 0 1}$ \\
Charlson comorbidity index & 1.436 & $0.902-2.415$ & 0.158 \\
Intubation at ED & 12.582 & $6.019-26.300$ & $<\mathbf{0 0 1}$ \\
Length of stay in the ED & 1.649 & $1.458-1.865$ & $<\mathbf{0 . 0 0 1}$ \\
\hline MAP: mean arterial pressure; GCS:Glasgow Coma Scale; ED: emergency department; CI: confidence interval; OR: odds ratios.
\end{tabular}

scores had no significant effect on mortality rates. Contrarily, underlying cancer diagnosis was a statistically significant predictor of mortality. In older adult patients with cancer, factors such as radiotherapy, chemotherapy and an increased risk of infection can be important risk factors for ICU mortality.

Many studies have shown that prolonged stay of critically patients in the ED and delayed admission to the ICU increase mortality $(24,25)$. In our study, the ICU mortality rate was 2.4 times higher when patients transferred to the ICU and had stayed in the ED longer than24 hours. A multicenter study in the United States involving 50,000 critically ill patients found that in-hospital mortality was 1.5 times higher in patients with more than six hours of ED stay (24). Cardoso et al. found that each hour of ED stay resulted in a $1.5 \%$ increase in ICU mortality (25). Likewise, in our study, there was a significant relationship between the duration of ED stay and ICU mortality. Each hour of ED stay increased the ICU mortality rate 1.66 times. Multiple concomitant diseases in older adult patients, difficulty in selfexpression, admission to the ED for nonspecific reasons, a higher probability of serious underlying illness requiring differential diagnosis, and the need for consultation can lead to prolonged stay of these patients in the ED. Prolonged monitoring of critically ill patients in the ED negatively affects the quality of ED patient care (26).

This study has some limitations. First, the retrospective nature of the study restricted data to those routinely collected. Our retrospective study design may be related to selection biases, because this study only included patients admitted to the ICU. Second, this was a single center study. Third, this study focused on patients' initial diagnosis. The initial clinical picture may be ambiguous in older patients therefore, there may be differences between intensive care admission diagnosis and recent diagnosis. Further studies involving a large number of centers are needed to confirm our results.

In conclusion, although older adult patients have high ICU mortality, age is not an independent factor associated with ICU mortality. MAP, GCS, the need for intubation, underlying cancer diagnosis, and the duration of the ED stay should all be considered when establishing prognoses. The presence of one or more of the identified risk factors can help clinicians make decisions regarding the admissions of older adult patients to the ICU.

Ethics Committee Approval: Ethical Committee of Aksaray University Faculty of Medicine with a protocol number of 2020/03-56 and conducted in accordance with the Declaration of Helsinki and Good Clinical Practices.

\section{References}

1. Ross MA, Compton S, Richardson D, et al. The use and effectiveness of an emergency department observation unit for elderly patients. Ann Emerg Med. 2003;41(5):668-77.

2. Guidet B, Leblanc G, Simon T, et al. Effect of Systematic Intensive Care Unit Triage on Long-term Mortality Among Critically Ill Elderly Patients in France: A Randomized Clinical Trial. JAMA. 2017;318(15):1450-9.

3. Boumendil A, Somme D, Garrouste-Orgeas M, et al. Should elderly patients be admitted to the intensive care unit? Intensive Care Med. 2007;33(7):1252.

4. Demoule A, Cracco C, Lefort Y, et al. Patients aged 90 years or older in the intensive care unit. J Gerontol A Biol Sci Med Sci. 2005;60(1):129-32.

5. Ely WE. Optimizing outcomes for older patients treated in the intensive care unit. Intensive Care Med. 2003;29(12):2112-5.

6. Nguyen YL, Angus DC, Boumendil A, et al. The challenge of admitting the very elderly to intensive care. Ann Intensive Care. 2011;1(1):29.

7. Yu W, ASh AS, Levinsky NG, Moskowitz MA. Intensive care unit and mortality in the elderly. J Gen Intern Med. 2000;15(2): 97-102.

8. Garrouste-Orgeas M, Boumendil A, Pateron D, et al. Selection of intensive care unit admission criteria for patients aged 80 years and over and compliance of emergency and intensive care unit physicians with the selected criteria: An observational, multicenter, prospective study. Crit Care Med. 2009;37(11):2919-28.

9. Guidelines for intensive care unit admission, discharge, and triage. Task Force of the American College of Critical Care Medicine, Society of Critical Care Medicine. Crit Care Med. 1999: 27(3):633-8

10. Kramer AA, Higgins TL, Zimmerman JE. The association between ICU readmission rate and patient outcomes. Crit Care Med. 2013; 41:24-33.

11. Charlson ME, Pompei P, Ales KL, et al. A new method of classifying prognostic comorbidity in longitudinal studies: development and validation. J Chronic Dis. 1987;40(5):37383.

12. Vosylius S, Sipylaite J, Ivaskevicius J. Determinents of outcome in elderly patients admitted to the intensive care unit. Age and Aging. 2005; 34:157-162.

13. Fuchs L, Chronaki CE, Park S, et al. ICU admission characteristics and mortality rates among elderly and very elderly patients. Intensive Care Med. 2012;38(10):1654-61.

14. Somme D, Maillet JM, Gisselbrecht M, et al. Critically ill old and the oldest-old patients in intensive care: short- and longterm outcomes. Intensive Care Med. 2003;29(12):2137-43. 
15. Andersen FH, Kvåle R. Do elderly intensive care unit patients receive less intensive care treatment and have higher mortality? Acta Anaesthesiol Scand. 2012;56(10):1298-305.

16. Ducos G, Mathe O, Balardy L, et al. Influence of age on decision-making process to limit or withdraw life-sustaining treatment in the intensive care unit $-\mathrm{a}$ single center prospective observational study. $J$ Frailty Aging. 2017;6(3):148-53.

17. Flaatten H, De Lange DW, Morandi A, et al. The impact of frailty on ICU and 30-day mortality and the level of care in very elderly patients ( $\geqslant 80$ years). Intensive Care Med. 2017; 43(12):1820-8

18. Heyland DK, Stelfox HT, Garland A, et al. Canadian Critical Care Trials Group and the Canadian Researchers at the End of Life Network. Predicting performance status 1 year after critical illness in patients 80 years or older: development of a multivariable clinical prediction model. Crit Care Med. 2016; 44(9): 1718-26.

19. Hwang LC, Hsu CP, Tjung JJ, et al. Predictors of in-hospital mortality in oldest-old patients in Taiwan. Int $\mathrm{J}$ Gerontol. 2013;7(1):22-6.
20. Bo M, Massaia M, Raspo S, et al. Predictive factors of inhospital mortality in older patients admitted to a medical intensive care unit. J Am Geriatr Soc. 2003; 51(4):529-33.

21. Knaus WA, Draper EA, Wagner DP, et al. APACHE II: A severity of disease classification system. Crit Care Med. 1985;13(10):818-29.

22. Le Gall JR, Lemeshow S, Saulnier F. A new Simplifed Acute Physiology Score (SAPS-II) based on a European/North American multicenter study. JAMA. 1993; 270(24):2957-63.

23. Norena M, Wong H, Thompson WD, et al. Adjustment of intensive care unit outcomes for severity of illness and comorbidity scores. J Crit Care. 2006; 21(2):142-50.

24. Chalfin DB, Trzeciak S, Likourezos A, Baumann BM, Dellinger RP; DELAY-ED study group. Impact of delayed transfer of critically ill patients from the emergency department to the intensive care unit. Crit Care Med. 2007;35(6):1477-83.

25. Cardoso LT, Grion CM, Matsuo Tet al. Impact of delayed admission to intensive care units on mortality of critically ill patients: a cohort study. Crit Care. 2011;15(1): R28.

26. Beynon T, Gomes B, Murtagh FE, et al. How common are palliative care needs among older people who die in the emergency department? Emerg Med J. 2011;28(6):491-5. 